\title{
Drömmen som gick i kras. Alvar Aaltos centrumplan för Helsingfors 1959-1972: Bakgrund, utformning och bemötande i en samtida kontext
}

Eva Johansson

Eva Johansson, Drömmen som gick i kras. Alvar Aaltos centrumplan för Helsingfors 1959-1972. Bakgrund, utformning och bemötande $i$ en samtida kontext (Åbo Akademi 2018) www.doria.fị! handle/10024/398

\section{LECTIO .}

Under åren 1959-1972 arbetade Alvar Aalto med centrumplanen för Helsingfors. Hans målsättning var att skapa ett för staden karaktäristiskt inre ansikte med vidsträckta vyer. Han var medveten om att uppgiften var problemfylld. Fem år innan han fick uppdraget konstaterade han i Hufvudstadsbladet:
Att lyckas här, det är uppgiften för vår generation, en uppgift värd nästan vilka mödor som helst. Det är här kring detta problem det sist och slutligen kommer att visa sig om vår stad har tillräckligt av kvarbliven eller förvärvad kultur för att kunna ge ett arv av kvalitet efter sig.

Liksom för många före honom skulle det visa sig blir en övermäktig uppgift. När jag på 1970-talet flyttade till Helsingfors efter ett år i Tyskland och intensivt resande i Mellaneuropa undrade jag hur det var möjligt att området framför Riksdagshuset närmast påminde om en bakgård. Efter att jag insett att man faktiskt försökt skapa något enastående i flera repriser under 1900-talets första hälft kom jag under mina magisterstudier så småningom fram till Aaltos förslag. Jag undersökte hur det kom till och mottogs, men min nyfikenhet var inte stillad. Det fanns många obesvarade frågor. Varför förverkligades planen inte fastän stadsfullmäktige godkände den som utgångspunkt för planeringen två gånger? Varför blev det trots det positiva bemötandet snabbt motigt? Varför kritiserades planen och Aalto i slutet av 1960-talet? För att klargöra orsakerna ville jag placera Aalto och centrumplanen $\mathrm{i}$ ett nationellt och internationellt sammanhang. Att reda ut hur beslutsprocessen utvecklade sig i en politisk kontext blev det mest intressanta skedet av min forskning. Granskningen visade sig blir en verklig detektivhistoria.

Fascinerande var också att jämföra Aaltos texter och planbeskrivningar med den internationella arkitektorganisationen CIAM:s åsikter om stadsplanering. Av studien framgår att Aalto hörde till de första som insåg bristerna i den funktionella stadens centrum och önskade förbättra det. Helsingfors centrumplan var ett exempel på hur ett centrum för en huvudstad 


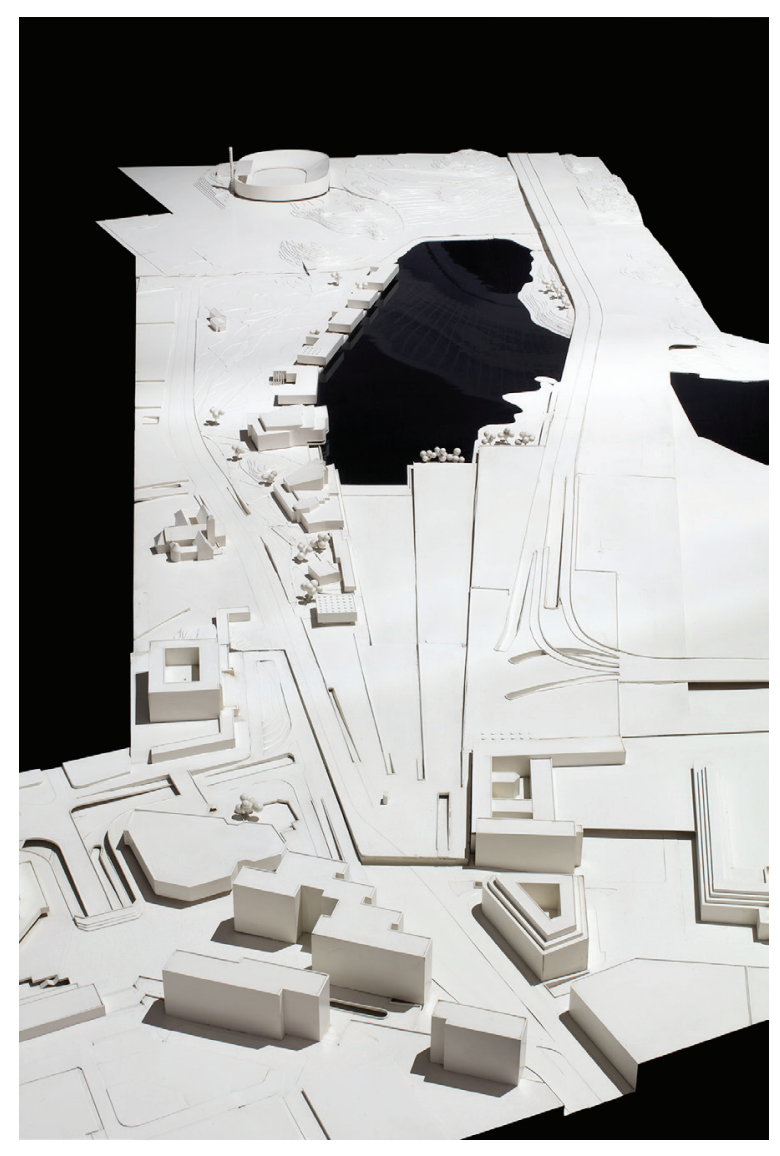

Bild 1. Alvar Aalto, miniatyrmodell av centrumplanen för Helsingfors

centrum, s.a. (1961?), Längd 7380 mm, bredd 1950 mm, Alvar Aalto museets samlingar. Foto: Jussi Tiainen. kunde utformas. Han ansåg till skillnad från de ortodoxa funktionalisterna att det måste skapas möjlighet att träffas utanför hemmen när bostäderna blev allt mindre. Enligt Aalto var det viktigt att de offentliga byggnaderna var samlade. Då kunde en samverkan uppstå. Aaltos platsbundna och på historien grundade så kallade "organiska" centrumplanering blev med likasinnades försök dock mötta av kritik inom CIAM. Av granskningen framgår också att avantgardet, som påskyndat organisationens upplösning, blev förebild för dem som i Finland önskade bilda en motpol till Aaltos dominerande ställning.

Jag började med traditionell empirisk forskning för att få en ram för händelseförloppet. Det var dock svårt att hitta en röd tråd fastän jag korsläste flera kommittéers protokoll. Det var som om någonting skulle ha saknats, men jag visste inte vad. Det fanns luckor och motsägelser i dokumenten. En stor oklarhet rådde också beträffande det alternativa förslaget som presenterades 1969. Jag hittade inga förklaringar till hur förslaget hade kommit till och varför. Med detta i bagaget började jag kontakta trafikplanerare, arkitekter och politiker som varit involverade i centrumplaneringen under undersöksperioden. Min arbetsmetod fick karaktären av fallstudie. Jag började fokusera på detaljer och jämföra skriftligt material med de tillfrågades minnesbilder och berättelser. Rädslan att de intervjuade skulle ha varit ovilliga att delge information var obefogad. Aaltos centrumplan låg inte för nära i tiden. Respondenterna önskade att förhållandena reds ut, gav dokument och delade gärna med sig av sina minnen. Dessa minnesbilder blev avgörande för återskapandet av händelseförloppet i de fall det inte fanns skriftliga källor att tillgå.

Fallstudiens styrka ligger i att många typer av empiriskt material kan hanteras samtidigt. Många variabler och deras samverkan kan granskas. Tack vare djupgående granskning har samband upptäckts och de inblandade personernas agerande fått en förklaring. Pierre Bourdieus begrepp har använts för att upptäcka relationer mellan intressegrupperna och deras inbördes maktrelationer. Målet är att ge en så holistisk bild som möjligt av processen runt Aaltos centrumplan och att öka förståelsen av varför planen inte förverkligades.

Fallstudiens största nackdel är det muntliga materialets tillförlitlighet. Eftersom minnet inte är statiskt kan absolut sanning inte uppnås. Det blir således läsarens uppgift att avgöra om föreliggande berättelse verkar trovärdig och kan anses bidra till förståelsen av händelseförloppet. En annan nackdel är att metoden är mycket tidskrävande och genererar en stor mängd material. Det har varit mest utmanande att presentera beslutsprocessen på ett strukturerat men samtidigt engagerande och läsarvänligt sätt. 
Av studien framgår att de inblandade personerna hade olika åsikter om metroprojektets inverkan på centrumplanen. Flertalet ansåg att Aaltos centrumplan och metron behandlades som två totalt särskilda frågor, men några ansåg att de insett att vissa övervägda ageranden hade gynnat metroprojektet. Detta ledde till att jag började nysta upp händelser och handlingar som föregick metrobeslutet 1969.

Min slutsats är att centrumplanen förhalades både i planeringsskedet och i beredningen inför fullmäktigebehandlingen 1966 för att gynna metroprojektet.

I slutet av 1960-talet övergick bromsningstaktiken som främst skett bakom kulisserna, i öppen kritik av centrumplanens utformning och stadsplaneideologiska grund. Därtill bidrog den interna kraftmätningen inom arkitektkåren till att Aaltos uppfattning om ett gott centrum ansågs otidsenlig. Både politiker och tjänstemän omfattade åsikten. Ett alternativ skapades i samförstånd på stadsplaneringskontoret. Det kom att utgöra grund för planeringen under början av 1970-talet. Alternativet var även utgångspunkt för Aaltos reviderade förslag från 1972. Förslaget fördes inte till stadsfullmäktige. Aalto kan kritiseras för att han inte var tillräckligt lyhörd. Om det berodde på att tiden gått honom förbi eller på hans åsikt att planering som baserar sig på teori aldrig ger ett gott resultat är svårt att säga. Det är i varje fall uppenbart att han inte märkte att trafik- och stadsplanerarna hade politikernas stöd för sitt agerande.
Trots att förslaget motarbetades överlevde dess förtjänster flera duster och stadsplanetävlingen på 1980-talet. År 1991 lades centrumplanen dock slutgiltigt till handlingarna. Aaltos målsättning att skapa en helhet som kunde mäta sig med Senatstorget fick inte längre politikernas stöd.

Vad var det då man kritiserade och inte ville ha, men som segt följde med och kommer till uttryck även i dagens lösningar? Det var de enskilda elementen, delarna man fäste sig vid. De offentliga byggnaderna var för många och på fel plats, torget för stort och ödsligt. Därtill önskade många bevara Tölöviken orörd. Helheten tyckte man att var genial, medan kritiken av detaljerna och motståndet mot motorvägen från Böle in i absoluta centrum tilltog med tiden.

Aaltos centrumplan var ett resultat av 1950-talets ideal och när det blev dags att vidarebearbeta den för ett förverkligande hade tiderna förändrats. Nya samhällsideal och behov hade uppstått. De politiska prioriteringarna var helt enkelt andra och överensstämde inte med Aaltos livs- och stadsplanefilosofi. På ett nordiskt seminarium i Uleåborg 1968 sammanfattade han sin syn på human stadsplanering. Han upprepade sitt livslånga rättesnöre att man alltid bör utgå från människan som individ och kollektiv. Trafiken var människan tjänare, inte huvudmotivet i hennes liv. Arkitekten skulle fungera som en orkesterledare som skulle koordinera de olika kraven för att
Bild 2. Aalto, Alvar, Helsingfors centrumplan 1960, Helsingfors stadsarkiv, K 345, protokoll II/1960, bilaga.

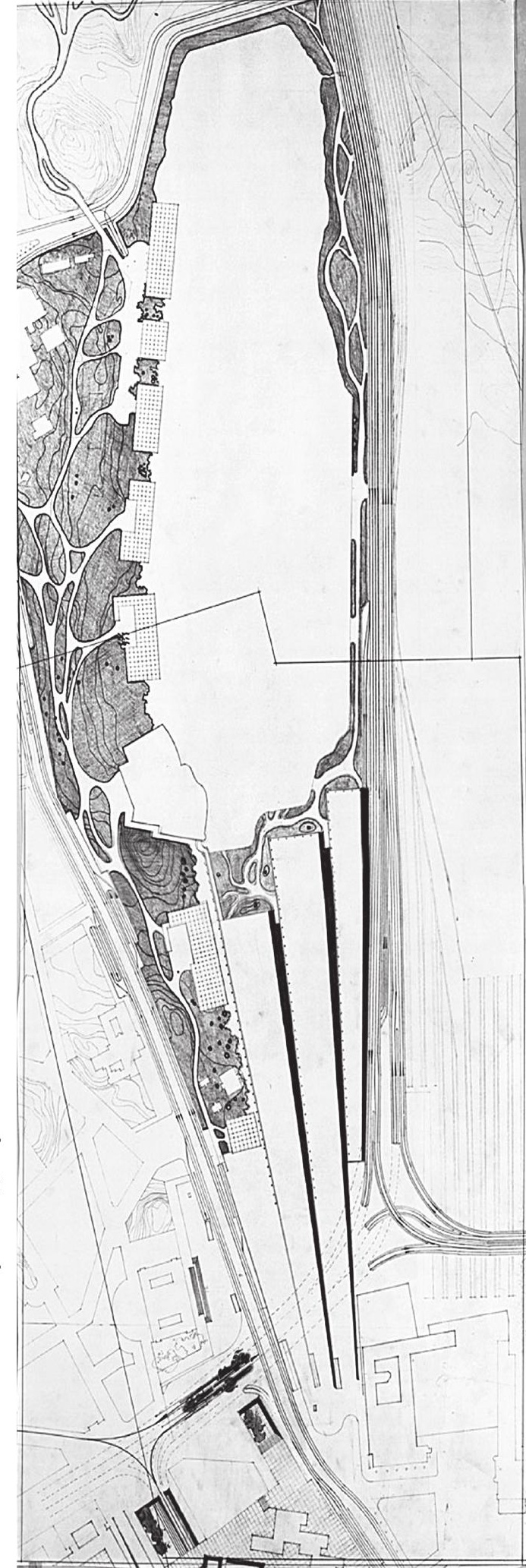


åstadkomma ett harmoniskt slutresultat. Han var mån om att de offentliga byggnaderna i städernas centrum måste representera det andliga livet. Form är inte nog utan innehållet måste stå i kontakt med naturen och dess viktigaste beståndsdel, människan.

Aalto kunde dock inte tänka sig att bevara orörd natur i städernas centrum. Hans åsikter om förhållandet mellan natur och arkitektur går tillbaka till 1920-talet då han skrev i Sisä Suomi:

Man inbillar sig att den rena, ursprungliga naturen med dess speciella trollmakt är milsvitt överlägsen det landskap där spåren av människohandens verksamhet kan skönjas, även i de fall där den "mänskliga stämpel” fogats till landskapet på ett harmoniskt och förhöjande sätt. Vi nordbor och speciellt vi finnar är i hög grad böjda för skogsdrömmeri, [...]. Ibland tycker vi dock att vi inte har tillräckligt mycket ren natur till vårt förfogande och då försöker vi plantera den vilda skönheten vid våra hemknutar. Principen bör dock vara den motsatta, nämligen att vi utgår från den miljö där vi bor och till den fogar bebyggelse på ett sätt som förädlar det ursprungliga landskapet.

I Helsingfors önskade Aalto förädla Tölöviken och införliva den i stadsstrukturen. Det behövdes inga regelrätta parker i centrum. Grönstråk som ledde ut $\mathrm{i}$ till fri natur räckte. Beslutsfattarna föredrog dock orörd natur framom urbanitet, och Tölövikens vassbevuxna stränder finns kvar.

Finlandiahuset och dess kongressdel ger i dag en liten bild av hur Tölövikens västra strand skulle ha gestaltats enligt Aaltos plan. Områdets längdbetonade karaktär är framträdande. Det var ett av Aaltos absolut viktigaste villkor för utformningen. Trots att man i delgeneralplanen 1991 utgick från att området söder om Tölöviken skulle vara mångfunktionellt har kulturinstitutionerna samlats där. Den för Aalto så viktiga samverkan kan uppstå. Alla av honom föreslagna offentliga byggnader, utom informationscentret för arkitektur, har förverkligats. Huvudbiblioteket byggdes enligt tidens krav i Böle men är nu på väg tillbaka i form av centrumbiblioteket Ode. Musikhuset har rests på den plats Aalto reserverade för en liten byggnad för Finlands Akademi. Placeringen av operan går tillbaka till Aaltos reviderade plan från 1972 även om byggnaden dragits bort från strandlinjen.

Området intill järnvägen som i planeringsskedet tillhörde staten har bebyggts. Lösningen var inte helt främmande för Aalto. Det skulle vara möjligt att bygga både längs järnvägen och på Terrasstorget om utvecklingen krävde det.

Sanomahuset kommer tillsammans men biblioteket att bilda en länga av byggnader som kan jämföras med byggnadsvolymerna som delade Terrasstorget i den reviderade planen. Öppenheten mot norr såg
Aalto som synnerligen viktig och den finns delvis kvar. Utsikten öppnar sig dock inte från Mannerheimvägen utan mellan Kiasma och Sanomahuset samt inifrån byggnaderna.

Bilfria områden finns både i Kampen och nedanför Riksdagshuset. Busstationen placerades till slut $\mathrm{i}$ Kampen och tack vare den långa planeringsprocessen kunde den byggas helt under jord. I Kampen restes Elhusets tillbyggnad enligt Aaltos ritningar och flera av byggnaderna i närheten tar upp Elhusets arkad. Aalto insåg behovet av att utveckla Böle och området har fungerat väl som avlastningsområde.

En hel rad av Aaltos idéer har alltså beaktats fastän endast en byggnad, Finlandiahuset, förverkligats helt enligt hans ritningar. Sämre gick det med hans viktigaste målsättning och vision - en harmonisk helhet som beaktar och framhäver platsens egenart. Landskapets form har inte utnyttjats eller intensiverats utan byggnaderna har rest en i sänder i gropen nedanför Riksdagshuset utan någon helhetsvision. Öppenheten och utsikten från Riksdagshusets trappa mot Berghäll, som Aalto ansåg specifik för Helsingfors, har försvunnit. Terrasstorget blev Medborgartorget i form av en öppen plan för tillfälliga evenemang. Torget har dock ingen stadsbyggnadskonstnärlig uppgift. Enligt Aalto skulle summan av delarna ge ett mervärde som enligt min mening inte uppnåddes. Men lösningen representera väl dagens mångkulturel- 
la värld där enhet inte är ett värde i sig.

Man kan med fog säga att Aaltos insatser på centrumplaneringens område har underskattats. Han tänkte globalt långt innan globaliseringen var aktuell. Han använde sig av internationella trender och ideal, omformade dem för tillämpning i lokala förhållanden. Han ansåg att människan behöver en lokal identitet för att kunna verka globalt och att arkitekturen, som alltid är lokal, kan innehålla spår av vad som sker internationellt. Aaltos målsättning var att med arkitekturens medel skapa ramar för ett gott liv. Han poängterade symbolernas betydelse för människans psykologiska välbefinnande och sökte kontinuerligt efter arkitektoniska uttryck för en demokrati. Han förutsåg också turismens växande betydelse och poängterade att städerna måste ta vara på och utveckla sin egenart för att skilja sig från mängden. Aalto önskade ge Finland och Helsingfors något stort i likhet med Akropolis. Men för att genomföra något exceptionellt behövdes det enligt Aalto en medveten kulturell vilja. Den saknades och man kan fråga sig om den saknas än i dag.
FD Eva Johansson har arbetat

som värdinna och hotellchef

på Hanaholmen-Hanasaari,

Kulturscentrum för Finland och

Sverige 1975-90. Därefter bodde hon

i Frankrike 1990-95 och studerade

franska vid Université des Sciences

Humaines de Strasbourg. Hon

avlade filosofie examen år 2003

och disputerade vid Åbo Akademi i

september 2018.

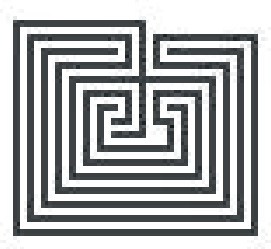

